\title{
Pengaruh Pendapatan Perempuan Terhadap Kemiskinan dan Ketimpangan Pendapatan: Bukti Data Panel di Aceh
}

\author{
Ikhsan $^{1^{*}}$, Zulkifli $^{2}$ \\ 1,2 Fakultas Ekonomi dan Bisnis, Universitas Syiah Kuala, Kota Banda Aceh, \\ Provinsi Aceh, Indonesia.
}

\begin{abstract}
Abstrak. Penelitian ini menganalisis pengaruh pendapatan perempuan terbadap kemiskinan dan ketimpangan pendapatan. Menggunakan data panel 23 kabupaten kota di Aceh selama periode 2010-2020, regresi panel pendekatan fixed-effect diterapkan sebagai model analisis data. Temuan penting penelitian ini adalah, pendapatan perempuan secara signifikan dapat menurunkan tingkat kemiskinan. Semakin besar kontribusi pendapatan perempuan dalam rumah tangga, semakin rendah tingkat kemiskinan. Namun demikian, peningkatan kontribusi tersebut juga secara nyata berdampak. buruk pada distribusi pendapatan. Semakin besar kontribusi pendapatan perempuan, semakin tinggi ketimpangan.
\end{abstract}

Kata kunci: Pendapatan Perempuan; Kemiskinan; Ketimpangan Pendapatan; Regresi Panel Pendekatan FixedEffect.

Abstract. This study analyzes the effect of women's income on poverty and income inequality. Using panel data from 23 districts in Aceh during the 2010-2020 period, the fixed-effect approach panel regression was applied as a data analysis model. An important finding of this study is that women's income can significantly reduce poverty levels. The greater the contribution of women's income in the household, the lower the poverty rate. However, the women's income also significantly adversely affects the income distribution. The higher the women's income, the higher the inequality.

Keywords: Women's Incomme; Poverty Rate; Income Inequality; Panel Regression.

*Author. Email: ikhsan30303@unsyiah.ac.id 1*, zulkifli_tok@unsyiah.ac.id 2 


\section{Pendahuluan}

Kemiskinan dan ketimpangan pendapatan merupakan variabel makro ekonomi yang keberadaannya dianggap sebagai penghambat pembangunan ekonomi. Kemiskinan dan ketimpangan yang tinggi, menyulitkan upaya pemerintah dalam meningkatkan pertumbuhan ekonomi dan memperbaiki kesejahteraan masyarakat (Marrero \& Serven, 2021). Bahkan kedua variabel ini memiliki konsekuensi sosial ekonomi yang lebih luas seperti penurunan kesempatan kerja, meningkatnya pengangguran dan bahkan dapat mendorong munculnya tindakan kriminal di masyarakat (Anser et al., 2020). Karena itu, penurunan kemiskinan dan perbaikan distribusi pendapatan merupakan salah satu tujuan pembangunan itu sendiri. Keberhasilan pembangunan ekonomi tidak lagi menempatkan pendapatan per kapita sebagai ukuran tunggal, tetapi sejauhmana pembangunan tersebut dapat menurunkan kemiskinan dan memperbaiki distribusi pendapatan agar kesenjangan kaya dan miskin di masyarakat dapat diperkecil. Sehingga dalam konsep pertumbuhan inklusif, penurunan kemiskinan dan ketimpangan pendapatan juga sering digunakan sebagai indikator pertumbuhan yang berkualitas (Tridico, 2009).

Seiring dengan perkembangan ekonomi daerah, tingkat kemiskinan dan ketimpangan pendapatan di Aceh mengalami perubahan dari tahun ke tahun. Secara umum, tingkat kemiskinan mengalami penurunan. Pada tahun 2010, tingkat kemiskinan di Aceh sebesar 19,95 persen. Angka ini menurun menjadi sebesar 17,08 persen tahun 2015. Meskipun pada level provinsi tingkat kemiskinan mengalami penurunan, tetapi pada level kabupaten kota diperoleh data empiris bahwa tingkat kemiskinan berbeda antar daerah (Muliadi \& Amri, 2019). Dalam periode waktu yang sama, ketimpangan pendapatan pada masyarakat di daerah tertentu berbeda dengan daerah lainnya, dan umumnya cenderung meningkat. Peningkatan ketimpangan ini ditunjukkan oleh kenaikan Gini rasio masing-masing daerah (Amri \& Adi, 2021). Pada tahun 2010, Gini rasio Aceh tercatat sebesar 0,294. Angka ini meningkat menjadi sebesar 0,330 pada tahun 2015. Hal ini mengindikasikan bahwa selama periode tahun tersebut, distribusi pendapatan di
Aceh semakin tidak merata dan kesenjangan (gap) antara kaya miskin semakin melebar.

Dalam upaya menurunkan tingkat kemiskinan dan memperbaiki taraf hidup masyarakat, eksistensi perempuan dalam mendukung ekonomi keluarga sangat diharapkan. Menyadari hal tersebut, pemerintah telah berupaya mencanangkan program pemberdayaan ekonomi perempuan (KPPPA RI, 2012). Bahkan pemerintah menganggap bahwa perempuan tidak hanya dapat berkontribusi bagi perbaikan kehidupan keluarga mereka, tetapi juga bermakna bagi perkembangan ekonomi nasional. Sejumlah kajian mengisyaratkan bahwa pemberdayaan perempuan dalam bidang ekonomi mampu menurunkan tingkat kemiskinan (Kabeer, 2020; Adnan \& Amri, 2021). Peran aktif perempuan dalam kegiatan ekonomi produktif tidak hanya berkontribusi bagi peningkatan pendapatan, tetapi juga berdampak positif pada peningkatan taraf hidup keluarga (Wei et al., 2021; Okolie et al., 2021). Hal ini mengindikasikan bahwa pendapatan perempuan mampu menurunkan tingkat kemiskinan di masyarakat. Adanya pengaruh pendapatan perempuan terhadap penurunan kemiskinan diperkuat dengan hasil kajian empiris yang dilakukan Adnan \& Amri (2020) yang membuktikan bahwa kontribusi pendapatan perempuan dalam rumah tangga secara signifikan dapat menurunkan tingkat kemiskinan.

Meskipun keterlibatan perempuan dalam kegiatan ekonomi dapat menghasilkan pendapatan dan berkontribusi signifikan terhadap penurunan kemiskinan, sejumlah kajian empiris menemukan bahwa partisipasi aktif perempuan dalam bidang ekonomi berdampak pada ketimpangan pendapatan di masyarakat. Ketimpangan yang lebih tinggi terkait dengan peningkatan partisipasi kerja perempuan dalam kegiatan ekonomi (Conroy et al., 2019). Hal ini dikarenakan peningkatan partisipasi kerja dan pendapatan perempuan biasanya terkonsentrasi pada keluarga dengan pendapatan laki-laki yang lebih tinggi, sehingga kontribusi perempuan dalam peningkatan pendapatan keluarga mendorong ketimpangan pendapatan antar keluarga semakin semakin melebar (Austen \& Redmond, 2013). Namun, bertolak belakang dengan hasil penelitian 
Conroy et al, sebelumnya penelitian empiris yang dilakukan Cancian \& Reed (1999) menemukan bahwa pendapatan perempuan dapat meningkatkan kesejahteraan keluarga, tetapi tidak berdampak pada ketimpangan pendapatan di masyarakat.

Sebagaimana dijelaskan sebelumnya, kemiskinan dan ketimpangan pendapatan terkait dengan pendapatan perempuan. Meskipun sejumlah peneliti telah membuktikan bahwa pendapatan perempuan berkontribusi positif pada penurunan kemiskinan, namun hubungan antara pendapatan perempuan dengan ketimpangan pendapatan masih menjadi pertanyaan terbuka. Artinya, hingga saat ini belum ada kesimpulan yang sama tentang dampak pendapatan perempuan dalam menjelaskan distribusi pendapatan di masyarakat. Karena itu, penelitian ini kembali menguji pengaruh pendapatan perempuan terhadap kemiskinan dan ketimpangan pendapatan dalam kontek Aceh. Selama ini, kajian kemiskinan dan ketimpangan di Aceh belum pernah menempatkan pendapatan perempuan sebagai predictor variable. Sehingga temuan penelitian dapat berkontribusi bagi pengayaan analisis tentang kemiskinan dan ketimpangan pendapatan di daerah ini.

Secara berurutan, paper ini disusun dalam lima bagian. Bagian berikutnya adalah data dan metode yang berisi informasi mengenai data yang digunakan dan model analisis yang diterapkan untuk menganalisis pengaruh pendapatan perempuan terhadap kemiskinan dan ketimpangan pendapatan. Bagian ketiga adalah hasil dan pembahasan, bagian menyajikan hasil statistik deskriptif masingmasing variabel. Terakhir bagian keempat adalah kesimpulan dan saran, serta implikasi penelitian bagi peneliti selanjutnya.

\section{Data dan Model Analisis}

Sesuai dengan fokus kajian yakni keterkaitan antara pendapatan perempuan dengan kemiskinan dan ketimpangan pendapatan di Aceh, maka kajian ini mengkombinasikan data time series selama periode 2010-2020 dengan data silang 23 kabupaten kota di Aceh. Seluruh data bersumber dari laporan Badan Statistik
Aceh. Pendapatan perempuan diproksi dari kontribusi pendapatan perempuan dalam keluarga yang diukur dengan persen. Selanjutnya kemiskinan adalah rasio penduduk miskin terhadap total penduduk yang juga diukur dengan satuan persen. Kemudian ketimpangan pendapatan diukur menggunakan Gini rasio. Indek ini dikenal sebagai ukuran yang paling umum digunakan untuk mengukur ketimpangan (Shao, 2021). Penggunaan Gini rasio sebagai ukuran ketimpangan pendapatan mengacu pada sejumlah peneliti sebelumnya (Anderson et al., 2016; Luptacik \& Nezinsky, 2019; Nazamuddin \& Amri, 2020; Amri \& Adi, 2021).

Mengingat kajian ini mengoperasionalkan data panel, maka model regresi yang digunakan untuk mengestimasi pengaruh pendapatan perempuan terhadap kemiskinan dan ketimpangan pendapatan adalah regresi panel. Sesuai dengan penempatan variabel, dimana kemiskinan dan ketimpangan diposisikan sebagai variabel dependen yang nilainya ditentukan oleh pendapatan perempuan sebagai predictor variable, maka regresi panel yang diterapkan dalam penelitian ini terdiri dari dua persamaan. Persamaan pertama memprediksi pengaruh pendapatan perempuan terhadap kemiskinan, dan persamaan kedua mengestimasi pengaruh pendapatan perempuan terhadap ketimpangan pendapatan. Secara ekonometrik, kedua persamaan tersebut seperti di bawah ini.

$\mathrm{MSK}_{\mathrm{it}}=\beta_{0}+\beta_{1} \mathrm{PP}_{\mathrm{it}}+\mu_{1}$

$\mathrm{GR}_{\mathrm{it}}=\beta_{0}+\beta_{1} \mathrm{PP}_{\mathrm{it}}+\mu_{2}$

Dimana MSK adalah simbol untuk tingkat kemiskinan, GR merepresentasikan Gini rasio (sebagai proksi dari ketimpangan pendapatan), dan PP adalah pendapatan perempuan. $i$ adalah kabupaten/kota ke- $i$ dimana $i=1,2, \ldots 23$, dan $t$ adalah periode tahun ke- $t,(2010,2011, \ldots$ 2020). $\beta_{0}$ pada persamaan 1 dan 2 adalah konstanta, $\quad \beta_{1}$ pada persamaan 1 merepresentasikan koefisien estimasi pendapatan perempuan terhadap kemiskinan, dan $\beta_{1}$ pada persamaan 2 merepresentasikan koefisien estimasi pendapatan perempuan terhadap ketimpangan pendapatan. Terakhir, $\mu_{1}$ dan $\mu_{2}$ adalah error term masing-masing persamaan. 
Kedua persamaan di atas diestimasi menggunakan pendekatan fixed effect. Pendekatan ini lebih umum digunakan dibanding pendekatan lainnya seperti random effect dan common effect (Astuti, 2010). Penggunaan pendekatan fixed-effect dalam estimasi data panel juga merujuk pada pendapat Baltagi (2008) yang menyatakan bahwa pendekatan ini dapat menghasilkan estimasi yang lebih akurat ketika jumlah cross-section data relatif lebih besar dibanding time-series nya.

Justifikasi pengaruh pendapatan perempuan terhadap kemiskinan dan ketimpangan pendapatan didasarkan pada signifikansi nilai koefisien estimasi $\left(\beta_{1}\right)$. Jika nilai $\beta_{1} \neq 0$ (p-value $<0,05)$ mengindikasikan bahwa pendapatan perempuan berpengaruh signifikan. Sebaliknya, jika $\beta_{1}=0$ (p-value $\left.>0,05\right)$ berarti bahwa pendapatan perempuan tidak berpengaruh signifikan.

\section{Hasil dan Pembahasan}

\section{Stastistik deskriptif}

Tingkat kemiskinan dan ketimpangan pendapatan pada kabupaten kota di Aceh berbeda antar daerah. Sejumlah daerah memiliki tingkat kemiskinan dan ketimpangan yang tinggi. Disisi lain juga terdapat daerah dengan kemiskinan dan ketimpangan relatif rendah. Selanjutnya, kontribusi pendapatan perempuan terhadap total pendapatan keluarga juga berbeda antara daerah yang satu dengan daerah lainnya. Menggunakan data panel 23 kabupaten kota di Aceh selama periode 20102020, parameter statistik deskriptif seperti ratarata, nilai maksimum, nilai minimum dan parameter statistik lainnya termasuk median dan standar deviasi. Hasil pengolahan data terhadap data panel tersebut menunjukkan nilai rata-rata kemiskinan sebesar $17,62 \%$, dengan nilai maksimum dan minimum masing-masing sebesar $26,23 \%$ dan 7,22\%. Selanjutnya, untuk ketimpangan pendapatan yang pengukurannya menggunakan Gini rasio, diperoleh nilai rata- rata sebesar 0,28 , dengan nilai maksimum dan minimum masing-masing sebesar 0,454 dan 0,186 . Untuk lebih jelasnya mengenai gambaran statistik deskriptif ketiga variabel penelitian seperti ditunjukkan dalam Tabel 1.

Tabel 1. Hasil statistik deskriptif

\begin{tabular}{lccc}
\hline & GR & $\begin{array}{c}\text { MSK } \\
(\%)\end{array}$ & PP (\%) \\
\hline Mean & 0,283 & 17,624 & 30,163 \\
Median & 0,283 & 18,011 & 28,990 \\
Maximum & 0,454 & 26,230 & 39,380 \\
Minimum & 0,186 & 7,219 & 21,730 \\
Std. Dev. & 0,039 & 4,051 & 4,581 \\
Obs & 253 & 253 & 253 \\
Sumber: Hasil kalkulasi penulis menggunakan E-Viens
\end{tabular}

Tabel 1 di atas juga memperlihatkan hasil statistik deskriptif pendapatan perempuan. Secara rata-rata, kontribusi pendapatan perempuan terhadap total pendapatan keluarga mereka sebesar $30,16 \%$. Nilai maksimum untuk variabel ini sebesar 39,38\%, dengan nilai minimum sebesar 21,73\%. Angka ini menjadi bukti kuantitatif adanya perbedaan kontribusi perempuan dalam menghasilkan pendapatan keluarga di masing-masing kabupaten kota di Aceh.

\section{Pengaruh pendapatan perempuan terhadap kemiskinan dan ketimpangan pendapatan}

Seperti penjelasan sebelumnya pada bagian metode, penerapan regresi panel dalam kajian ini dinyatakan dalam dua persamaan. Pendapatan perempuan dijadikan predictor variable bagi dua variabel dependen yakni kemiskinan (MSK) dan ketimpangan pendapatan (GR). Karena itu, proses prediksi pengaruh pendapatan perempuan terhadap kedua variabel dependen ini dilakukan dengan melalui penerapan dua model regresi panel sederhana. Menggunakan software E-Views sebagai alat bantu pengolahan data, hasil regresi panel untuk kedua model seperti ditunjukkan dalam Tabel 2. 
Tabel 2. Hasi regresi panel pendekatan fixed-effect

\begin{tabular}{|c|c|c|}
\hline \multirow{3}{*}{$\begin{array}{l}\text { Constanta \& } \\
\text { Predictors }\end{array}$} & \multicolumn{2}{|c|}{ Dependent Variables } \\
\hline & Model 1 & Model 2 \\
\hline & DV: MSK & DV: GR \\
\hline \multirow{4}{*}{$\beta_{0}$} & 50,051 & 0,005 \\
\hline & {$[20,270]$} & {$[0,093]$} \\
\hline & $(0,000)$ & $(0,926)$ \\
\hline & $-1,075^{* * *}$ & $0,010^{* * *}$ \\
\hline \multirow[t]{2}{*}{$\mathrm{PP}\left(\beta_{1}\right)$} & {$[-13,140]$} & {$[5,487]$} \\
\hline & $(0,000)$ & $(0,000)$ \\
\hline \multicolumn{3}{|c|}{ Effects Specification: Cross-section fixed } \\
\hline $\mathrm{R}^{2}$ & 0,903 & 0,563 \\
\hline Adjusted $\mathrm{R}^{2}$ & 0,893 & 0,519 \\
\hline F-statistic & 92,855 & 12,829 \\
\hline Prob(F-stat) & 0,000 & 0,000 \\
\hline DW-stat & 0,538 & 1,692 \\
\hline
\end{tabular}

pendapatan perempuan $\left(\beta_{1}\right)$ terhadap Gini rasio

Model 1 menempatkan kemiskinan (MSK) sebagai variabel dependent. Hasil pengolahan data menunjukkan bahwa pendapatan perempuan (PP) berpengaruh negatif dan signifikan terhadap kemiskinan, dengan koefisien estimasi $\left(\beta_{1}\right)$ sebesar $-1,075$ ( $p$-value $<$ $0,05)$. Setiap $1 \%$ kenaikan kontribusi pendapatan perempuan terhadap total pendapatan keluarga, dapat menurunkan tingkat kemiskinan sebesar $1,075 \%$. Hal ini mengindikasikan bahwa keberadaan pendapatan perempuan dapat menurunkan kemiskinan secara signifikan. Semakin besar kontribusi perempuan dalam menghasilkan pendapatan keluarga, semakin rendah tingkat kemiskinan. Sebaliknya, ketika kontribusi tersebut menurun, akan berdampak pada kenaikan tingkat kemiskinan. Temuan ini mengkonfirmasi hasil penelitian Adnan \& Amri (2020) dalam penelitian mereka menggunakan data panel provinsi di Indonesia yang juga membuktikan bahwa kontribusi perempuan dalam meningkatkan pendapatan keluarga berdampak signifikan pada penurunan kemiskinan. Sehingga program pemberdayaan gender yang berfokus pada peningkatan ekonomi perempuan direkomendasikan sebagai salah satu cara efektif untuk membantu masyarakat agar dapat keluar dari perangkap kemiskinan (Adnan \& Amri, 2021).

Bertolak belakang dengan pengaruhnya terhadap kemiskinan, peningkatan pendapatan perempuan justru meningkatkan ketimpangan pendapatan. Seperti ditunjukkan dalam model 2 pada Tabel 2 di atas, koefisien estimasi sebesar 0,010 (p-value $<0,05$ ). Hal ini mengindikasikan bahwa kontribusi pendapatan perempuan dalam keluarga berpengaruh positif dan signifikan terhadap ketimpangan pendapatan. Semakin besar kontribusi perempuan dalam menghasilkan pendapatan keluarga di suatu daerah, semakin tinggi pula ketimpangan pendapatan di daerah yang bersangkutan. Temuan ini mengkonfirmasi hasil penelitian Conroy et al. (2019) yang menemukan bahwa ketimpangan pendapatan yang lebih tinggi terkait dengan porsi yang lebih besar dari bisnis yang dimiliki dan dikelola oleh perempuan. Peningkatan pendapatan keluarga sebagai akibat meningkatnya partisipasi mereka dalam lapangan kerja, berdampak pada ketimpangan pendapatan di masyarakat. Sebelumnya, penelitian Austen \& Redmond (2013) juga membuktikan bahwa pendapatan perempuan mendorong ketimpangan pendapatan, karena pada umumnya pertumbuhan pendapatan perempuan terkonsentrasi pada rumah tangga yang sebelumnya juga memiliki pendapatan lebih tinggi. Bahkan perempuan dengan suami bekerja dan memiliki pendapatan relatif lebih besar, cenderung lebih produktif dalam kegiatan ekonomi dibandingkan perempuan dengan pendapatan suami relatif kecil. Hal inilah yang menyebabkan pengaruh negatif pendapatan perempuan terhadap distribusi pendapatan. Semakin besar pendapatan perempuan semakin buruk distribusi pendapatan yang diindikasikan dengan peningkatan Gini rasio. Hasil penelitian ini bertolak belakang dengan hasil penelitian 
Cancian \& Reed (1999) yang menyimpulkan bahwa perubahan pendapatan perempuan tidak mampu menjelaskan ketimpangan pendapatan di masyarakat.

\section{Kesimpulan dan Saran}

Seiring dengan proses pembangunan, tingkat kemiskinan dan ketimpangan pendapatan pada daerah kabupaten kota di Aceh mengalami perubahan dari tahun ke tahun. Di satu sisi terdapat daerah dengan kemiskinan dan ketimpangan yang tinggi, dan disisi lain sejumlah kabupaten kota mengalami tingkat kemiskinan yang rendah dan distribusi pendapatan relatif merata. Kontribusi pendapatan perempuan terhadap total pendapatan keluarga pada masing-masing kabupaten kota di Aceh juga relatif berbeda antara daerah yang satu dengan daerah lainnya. Penelitian ini mengestimasi dan menganalisis pengaruh pendapatan perempuan terhadap kemiskinan dan ketimpangan pendapatan di Aceh. Menggunakan data panel 23 kabupaten kota di Aceh selama periode tahun 2010-2020, penelitian memberikan dua kesimpulan empiris: Pertama, pendapatan perempuan secara signifikan dapat menurunkan tingkat kemiskinan. Semakin besar kontribusi perempuan dalam meningkatkan pendapatan keluarga mereka, semakin rendah tingkat kemiskinan. Hal ini menekan bahwa perempuan dengan kegiatan ekonomi yang mereka lakukan memiliki peran besar dalam upaya penurunan kemiskinan di Aceh. Kedua, meskipun berpengaruh negatif terhadap kemiskinan, pendapatan perempuan berdampak buruk pada distribusi pendapatan di masyarakat. Di daerah dengan kontribusi perempuan terhadap total pendapatan keluarga relatif lebih besar, tingkat ketimpangan di daerah tersebut juga lebih tinggi dibandingkan daerah dengan kontribusi pendapatan perempuan relatif kecil. Jadi, terdapat hubungan searah antara porsi pendapatan perempuan (dalam keluarga) dan ketidakmerataan pendapatan di masyarakat.

Merujuk pada kesimpulan di atas, maka upaya penurunan kemiskinan di Aceh dapat dilakukan melalui peningkatan partisipasi aktif perempuan dalam kegiatan ekonomi produktif. Namun demikian, arah pemberdayaan ekonomi perempuan harus benar-benar lebih difokuskan pada kelompok masyarakat miskin, agar upaya penurunan tingkat kemiskinan di satu sisi, sejalan upaya penurunan ketimpangan pendapatan di masyarakat. Pada akhirnya, temuan ini menyediakan bukti empiris bagi peneliti yang akan datang tentang pengaruh "ganda" pendapatan perempuan terhadap variabel makro ekonomi "antara penurunan kemiskinan dan pemerataan distribusi pendapatan".

\section{Daftar Pustaka}

Adnan, G., \& Amri, K. (2020). Pemberdayaan gender, pendapatan perempuan dan penurunan kemiskinan: Bukti data panel dari kawasan barat Indonesia. Media Ekonomi 28 (1), 37-56.

Adnan, G., \& Amri, K. (2021). Do gender empowerment and democracy reduce poverty rate? A cross-provinces evidence from western Indonesia. Economics and Sociology 14 (3), 54-71.

Amri, K., \& Adi, A. R. (2021). Apakah religiusitas keislaman mempengaruhi ketimpangan pendapatan? Bukti data panel dari provinsi aceh. Jurnal Ekonomi Dan Pembangunan, 29(2). Retrieved from https://jurnalekonomi.lipi.go.id/JEP/arti cle/view/704

Anderson, E., Jalles D’Orey, M. A., Duvendack, M., \& Esposito, L. (2016). Does government spending affect income inequality? A Meta-regression analysis. Journal of Economic Surveys, 31(4), 961-987. doi:10.1111/joes.12173

Anser, M. K., Yousaf, Z., Nassani, A. A., Alotaibi, S. M., Kabbani, A., \& Zaman, K. (2020). Dynamic linkages between poverty, inequality, crime, and social expenditures in a panel of 16 countries: two-step GMM estimates. Journal of Economic Structures, 9(1). doi:10.1186/s40008-020-00220-6 
Astuti, A. M. (2010). Fixed effect model pada regresi data panel, Beta, 3(2), 134-145.

Austen, S., \& Redmond, G. (2013). Male Earnings Inequality, Women's Earnings, and Family Income Inequality in Australia, 1982-2007. Journal of Economic Issues, 47(1), 33-62. doi:10.2753/jei00213624470102

Baltagi, B. H. (2008). Fixed Effects and Random Effects. The New Palgrave Dictionary of Economics, 1-6. doi:10.1057/978-1-34995121-5

Cancian, M., \& Reed, D. (1999). The Impact of Wives' Earnings on Income Inequality: Issues and Estimates. Demography, 36(2), 173. doi: $10.2307 / 2648106$

Conroy, T., Deller, S., \& Watson, P. (2019). Regional income inequality: a link to women-owned businesses. Small Business Economics, 56(1), 189-207. doi:10.1007/s11187-019-00224-y

Kabeer, N. (2020). Women's Empowerment and Economic Development: A Feminist Critique of Storytelling Practices in "Randomista" Economics. Feminist Economics, 26(2), 1-26. doi:10.1080/13545701.2020.1743

Luptáčik, M., \& Nežinský, E. (2019). Measuring income inequalities beyond the Gini coefficient. Central European Journal of Operations Research, 28(2), 561 578. doi:10.1007/s10100-019-00662-9

Marrero, G.A., \& Servén, L. (2021). Growth, inequality and poverty: a robust relationship?. Empirical Economics. https://doi.org/10.1007/s00181-02102152-x

KPPPA RI. (2012). Kebijakan dan Strategi Peningkatan Produktivitas Ekonomi Perempuan (PPEP), Kementerian Pemberdayaan Perempuan dan Perlindungan Anak, Jakarta.
Muliadi, M., \& Amri, K. (2019). Penerimaan Zakat dan Penurunan Kemiskinan di Aceh: Peran Dana Otonomi Khusus Sebagai Pemoderasi, Jurnal Imiah Ekonomi Islam, 5(3), 231-242.

Nazamuddin, B. S., \& Amri, K. (2020). Does goods and services spending reduce income inequality? A Panel data evidence from Indonesia. Regional Science Inquiry 12 (1), 87-102.

Okolie, U. C., Ehiobuche, C., Igwe, P. A., Agha-Okoro, M. A., \& Onwe, C. C. (2021). Women Entrepreneurship and Poverty Alleviation: Understanding the Economic and Socio-cultural Context of the Igbo Women's Basket Weaving Enterprise in Nigeria. Journal of African Business, $1-20$. doi:10.1080/15228916.2021.1874

Shao, B. (2021). Decomposition of the Gini index by income source for aggregated data and its applications. Computational Statistics, 36(3), 2135-2159. doi:10.1007/s00180-021-01069-4.

Tridico, P. (2009). Growth, Inequality and Poverty in Emerging and Transition Economies. Transition Studies Review, 16(4), 979-1001. doi:10.1007/s11300-009-01168.

Wei, W., Sarker, T., Żukiewicz-Sobczak, W., Roy, R., Alam, G. M. M., Rabbany, M. G., ... Aziz, N. (2021). The Influence of Women's Empowerment on Poverty Reduction in the Rural Areas of Bangladesh: Focus on Health, Education and Living Standard. International Journal of Environmental Research and Public Health, 18(13), 6909. doi:10.3390/ijerph1813690. 